INVESTIGATIONES LINGUISTICAE VOL. XL, 2018

(C) INSTITUTE OF LINGUISTICS - ADAM MICKIEWICZ UNIVERSITY

AL. NiePOdlegŁOŚCI 4, 60-874, POZNAŃ - POLAND

\title{
Specyfika pracy thmacza audiowizualnego na przykładzie wybranych komunikatów audiowizualnych
}

\author{
Paulina Borowczyk \\ INSTYTUT FILOLOGII ROMAŃSKIEJ, UNIWERSYTET IM. ADAMA MICKIEWICZA \\ AL. NIEPODLEGŁOŚCI 4, 61-874 POZNAŃ \\ pborowdamu .edu.pl
}

\begin{abstract}
The aim of the paper is to show the specificity and the complexity of audiovisual translation process. In the expository part of the paper I present the difference between translator of texts and audiovisual translator. I explain what elements take part in the construction of sense in audiovisual message and I show what kind of difficulties occur during the process of audiovisual translation (like technical restrictions). The FrancoGerman channel Arte is an example of a European company where the translation is used every day. The theoretical discussion is illustrated with the examples in which we can see how the translator use the informations from the screen to make polish subtitles shorter.
\end{abstract}

\section{Ustalenia wstępne}

Niniejszy artykuł skupia się wokół zagadnienia przekładu w środkach masowego przekazu, ze szczególnym uwzględnieniem dwujęzycznej telewizji oraz kina. Ma on na celu przybliżenie teoretycznych podstaw sztuki tłumaczenia audiowizualnego i specyfiki pracy tłumacza audiowizualnego względem tłumaczy tekstów pisanych oraz zwrócenie uwagi na główne trudności, z którymi trzeba się zmierzyć przekładając komunikaty audiowizualne. Specyfikę i kompleksowość procesu tłumaczenia audiowizualnego zgrabnie ujmuje motto, które przyświeca autorce publikacji Ttumaczenia filmowe w praktyce, Grażynie Adamowicz-Grzyb:

„nie ma filmów łatwych, każdy wymaga od tłumacza mniejszego lub większego zaangażowania: przełożenia fragmentu wiersza lub piosenki, wykreowania zabawnego dowcipu, trafnej metafory lub adekwatnego przysłowia, znajomości słownictwa dotyczącego konkretnej dziedziny wiedzy: lotów kosmicznych, sztuk walki czy brazylijskiej samby, znajomości topografii metropolii położnej na drugim krańcu świata albo dziejów malutkiej mieściny, którą z trudem udaje się odnaleźć na mapie. Twierdzenie, 
że praca tłumacza filmowego to lekki kawałek chleba należy między bajki włożyć.” (2013: 16).

Omawiając zatem specyfikę tłumaczenia audiowizualnego w pierwszej części artykułu będę chciała przede wszystkim zwrócić uwagę na fakt, że ze względu na jego multimodalność komunikatu audiowizualnego nie można tłumaczyć w taki sam sposób jak tekstu pisanego; przedstawię również, jakie elementy przyczyniają się do konstruowania sensu w komunikatach audiowizualnych oraz na konkretnym przykładzie zilustruję, w jaki sposób warstwa wizualna może wpłynąć na tłumaczony tekst. Na wybranym przykładzie, czyli na dwujęzycznym dzienniku telewizyjnym emitowanym we francusko-niemieckiej stacji Arte pokażę, jakie techniki tłumaczenia audiowizualnego są użyte w tego rodzaju komunikatach.

W drugiej części artykułu, bazując na jednej $\mathrm{z}$ metod transferu audiowizualnego, mianowicie na tłumaczeniu $\mathrm{w}$ formie podpisów, przeanalizuję pokrótce na jakie ograniczenia techniczne napotyka tłumacz w swojej pracy, a następnie pokażę, w jaki sposób tłumacz może wykorzystać obecność warstwy wizualnej, jak i uprzedniego kontekstu fabularnego w swoim tłumaczeniu w celu jego kondensacji.

\section{Założenia teoretyczne $w$ pracy tłumacza audiowizualnego}

Jak podaje Szarkowska:

„w przeciwieństwie do tekstów monosemiotycznych, np. nieilustrowanej książki, materiały audiowizualne określa się mianem polisemiotycznych, a więc złożonych z różnych kanałów informacyjnych wspólnie tworzących przekaz. W komunikacji filmowej można wyróżnić cztery kanały (zob. Gottlieb 1998: 245; Delabastita 1989: 199; Díaz-Cintas Remael 2007: 46-7; por. Pieńkos 1993: 136-7):

- kanał dźwiękowy werbalny, czyli dialogi, odgłosy werbalne w tle, słowa piosenek;

- kanał dźwiękowy niewerbalny, czyli muzyka, efekty dźwiękowe, odgłosy niewerbalne i dźwięki dochodzące $\mathrm{z}$ otoczenia;

- kanał wizualny werbalny, czyli napisy, znaki, nazwy ulic, gazet, dokumentów i inne informacje umieszczone na ekranie w formie pisanej;

- kanał wizualny niewerbalny, czyli kompozycja obrazów i scen.” (2009: 10-11)

Jak zauważa Palion-Musioł, „współczesny przekład audiowizualny nawiązuje do terminu zaproponowanego przez Jakobsona (1963), do tłumaczenia intersemiotycznego, zakładającego interpretację oraz objaśnianie znaków językowych za pomocą systemów znaków niejęzykowych z jednego języka na drugi, które przez swoją intertekstualność czy kontekst kulturowy mogą być dla widza niezrozumiałe” (2012: 97). Tomaszkiewicz natomiast precyzuje, że „tłumaczenie audiowizualne, zwane inaczej tłumaczeniem na potrzeby ekranu, jest specyficznym 


\section{Paulina Borowczyk: Specyfika pracy thumacza audiowizualnego na przykladzie wybranych komunikatów audiowizualnych}

rodzajem tłumaczenia łączącego $\mathrm{w}$ sobie elementy klasycznego tłumaczenia międzyjęzykowego i tłumaczenia intersemiotycznego, zwanego przez Jakobsona transmutacją" (2006: 100), powołując się jednocześnie na definicję Luykena określającą przekład audiowizualny „transferem językowym zastępującym tylko jeden element komunikatu, jakim jest tekst mówiony, na zasadach podobnych do innych typów tłumaczenia. Jednak nowy tekst musi tworzyć organiczny związek z innymi elementami dzieła, których transfer językowy nie może zmodyfikować." (Luyken 1991: 166 in Tomaszkiewicz 2006: 100).

Z cytowanych powyżej podejść wynika, że w komunikatach audiowizualnych (czy to będziemy mieli do czynienia $\mathrm{z}$ filmem, reportażem, dziennikiem telewizyjnym) współistnieje i współgra kilka elementów jednocześnie: obraz, dźwięk oraz partie mówione występujące pod postacią dialogów, monologów czy też narracji spoza kadru. „Tłumacz filmowy nie tyle powinien, ile musi znać strukturę dzieła filmowego, technologię i mechanizmy jego powstawania, aby móc skutecznie przełożyć jego treść, głównie zawartą w liście dialogowej, ale przecież nie tylko, na język odbiorcy przekładu." (Garcarz 2007: 40).

W jednym z rozdziałów swojej książki zatytułowanym „Film: komunikat kompleksowy” polska badaczka Elżbieta Plewa (2015: 72) słusznie zauważa, że rozumienie filmu jako nierozerwalnej całości reprezentowane jest $\mathrm{w}$ filmoznawstwie i zapewne stamtąd zostało przejęte przez translatorykę, Na potwierdzenie powyższej hipotezy autorka przytacza definicję audiowizualności zaproponowaną przez Hendrykowskiego:

W praktyce komunikacyjnej zjawisko audiowizualności opiera się na równoprawności, współdziałaniu i współdopełnianiu się znaków wizualnych i znaków audialnych w przekazach kinematograficznych, które w swej budowie stanowią swoiście zespoloną całość znaczeniową. Całość ta nie jest prostą sumą użytych w danym przekazie elementów wizualnych i audialnych, lecz jakością wyższego rzędu, będącą rezultatem zaawansowanej integracji semiotycznej obu rodzajów elementów. (...) (Hendrykowski 2003: 27 in Plewa 2015:72).

Biorąc zatem pod uwage fakt, że $\mathrm{w}$ tego rodzaju komunikatach „sens jest wypadkową znaczenia warstwy językowej, obrazu i dźwięków oraz relacji zachodzących między tymi elementami znaczącymi” (Tomaszkiewicz 2006: 97), tłumacz audiowizualny, w przeciwieństwie do tłumacza tekstów pisanych, musi w procesie translacji wziąć pod uwagę współistnienie tekstu z wyżej wymienionymi elementami. Wszystkie te elementy werbalne, wizualne oraz dźwiękowe składają się na film, tworzą go. Informacje docierają do widza/tłumacza kilkoma kanałami jednocześnie, tworząc jeden całościowy przekaz językowo-kulturowy. Tłumacz nie może zatem ograniczyć się wyłącznie do tłumaczenia warstwy słownej (listy dialogowej) bez wnikliwego oglądnięcia filmu od początku do końca i bez poddania go drobiazgowej analizie. Tylko dzięki takiemu podejściu tłumacz zdecyduje, za pomocą jakich środków językowych będzie mógł oddać sens treści zawartej $\mathrm{w}$ oryginalnym komunikacie audiowizualnym.

Jak zauważa Adamowicz-Grzyb, „bez zapoznania się z całym dziełem, znaczenie niektórych kwestii oraz sytuacji może być niejasne, tłumacz może nie 
wiedzieć nawet, jakiej płci jest bohater (w filmie anglojęzycznym), co wziął do ręki, jaki przedmiot pokazał lub położył na stole (...). Jeśli mamy do czynienia z typową listą dialogową, czyli jak sama nazwa wskazuje, zawierającą jedynie dialogi, bez obejrzenia obrazu wiele scen może być niezrozumiałych. Właśnie dlatego ten (...) etap pracy jest niezwykle ważny." (2013: 21).

Podczas tłumaczenia audiowizualnego wszystkie elementy znaczace występujące w przekazie mogą być, oddzielnie bądź razem, źródłem informacji dla tłumacza. Ponadto, współwystępowanie warstw językowej, wizualnej i dźwiękowej $\mathrm{w}$ procesie translacji ma ,zasadnicze znaczenie dla wyboru strategii translatorskich, decyduje (...) o kształcie przekładu, jego najrozmaitszych cechach charakterystycznych, zarówno językowych, jak i formalnych” (Belczyk 2007: 6), zmusza tłumacza do pomijania części informacji zawartych w tekście wyjściowym bądź dodawania innych. $Z$ drugiej zaś strony obecność warstwy wizualnej pozwala często tłumaczowi na kondensację tekstu tłumaczonego lub wręcz amputację niektórych fragmentów istniejących $\mathrm{w}$ oryginale. Ta złożoność komunikatu audiowizualnego, który wykorzystuje dźwięk, obraz i tekst do pełnego wyrażenia przekazywanych treści dotyczy również widza, który, ze względu na szybkość przekazu, jest zmuszony uchwycić sens w jednej chwili, bez możliwości dłuższej refleksji nad daną sceną bądź powrotu do uprzedniej sekwencji dialogowej, jak ma to miejsce w przypadku czytelnika.

W konsekwencji, w przypadku tłumaczenia tekstów pisanych mamy do czynienia z przejściem od tekstu wyrażonego w języku A do tekstu B, podczas gdy w przypadku tłumaczenia tekstów audiowizualnych będziemy mówić o transferze sensu $\mathrm{z}$ jednego kompleksu semiologicznego A do drugiego kompleksu semiologicznego B (Tomaszkiewicz 2006: 104), nie zapominając, że tłumacz audiowizualny dokonuje tylko i wyłącznie przekładu międzyjęzykowego, bez ingerowania $\mathrm{w}$ warstwę wizualną. Przekaz audiowizualny stanowi zatem pewną nieodłączną całość i w taki sposób powinien być postrzegany w procesie translacji. Przychylam się zatem w pełni do stwierdzenia, że tłumacz na potrzeby ekranu zawsze przekłada tekst filmowy (dialogi, monolog, narracja...) w odniesieniu do konkretnych kontekstów audialnego i wizualnego. Wielopłaszczyznowe analizy porównawcze pod kątem tłumaczenia filmów i programów telewizyjnych potwierdzają stanowisko, że między warstwami językową, wizualną i akustyczną zachodzą różnego rodzaje relacje i zależności, które tłumacz musi uwzględnić w swojej pracy, jednak nie tłumaczy on całego dzieła audiowizualnego, tylko niektóre jego komponenty (por. Borowczyk 2005, Tomaszkiewicz 2006, Belczyk 2007, Garcarz 2007, Bogucki 2010, Adamowicz-Grzyb 2013, Sikora 2013).

\section{Rozwiazania praktyczne w komunikatach audiowizualnych}

Przykładem medium, w którym tłumaczenie na potrzeby ekranu jest chlebem powszednim jest francusko-niemiecka telewizja Arte. Założona w 1991 roku Arte jest przykładem stacji, która nadaje swoje programy jednocześnie $\mathrm{w}$ dwóch krajach: we Francji i w Niemczech oraz w dwóch językach: niemieckim i francuskim.

Jak zauważa dziennikarka, Barbara Cöllen, na początku celem założycieli kanału było 


\title{
Paulina Borowczyk: Specyfika pracy thumacza audiowizualnego na przykladzie wybranych komunikatów audiowizualnych
}

\begin{abstract}
„zbliżenie społeczeństw francuskiego i niemieckiego na niwie kultury. W 2003 roku stacja trzymała nową siedzibę w dzielnicy europejskiej, w pobliżu Rady Europy i strasburskiej siedziby Parlamentu Europejskiego. Był to jasny sygnał, że twórcom ARTE nie chodzi tylko o niemiecko-francuskie porozumienie, ale też o szerszy, europejski kontekst, o emisję wysokiej jakości wielojęzycznych treści audiowizualnych. Ten unikalny projekt unijny jest też współfinansowany przez Komisję Europejską. ${ }^{1}$
\end{abstract}

Biorąc pod uwagę fakt, że widzowie francusko i niemieckojęzyczni oglądają każdy program $\mathrm{w}$ swoim ojczystym języku, korzystanie $\mathrm{z}$ usług tłumaczy audiowizualnych i ustnych jest tutaj na porządku dziennym. Jednym z programów stacji jest Arte Info, dwujęzyczny dziennik telewizyjny, w którym przeplatają się dwie metody transferu audiowizualnego, mianowicie tłumaczenie symultaniczne podczas wypowiedzi na żywo prezentera prowadzącego wiadomości lub wywiadu z zaproszonym do studia gościem oraz voice-over, czyli narracja, która ma miejsce, gdy lektor odczytuje komentarz towarzyszący materiałowi filmowemu. Wówczas oryginalna ścieżka dźwiękowa jest całkowicie wyciszona. Tłumaczenie tą techniką jest przygotowywane wcześniej, najczęściej przez tłumaczy freelancerów. Ponadto, wszelkie inskrypcje, które pojawiają się na ekranie są dwujęzyczne, np. w przypadku przedstawiania skrótu wiadomości na początku dziennika bądź $\mathrm{w}$ momencie, gdy wypowiada się jakaś osoba na ekranie, to widoczne są informacje o niej, np. funkcja, którą pełni bądź partia, którą reprezentuje. Poniższe przykłady ilustrują omówiony mechanizm:

Friedrich Merz

Président du groupe parlamentaire CDU

CDU-Fraktionschef

Pierre Lescure

Pdg de Canal plus

Generaldirektor von Canal plus

Refleksja i pytanie, które nasuwają się w związku z takim rodzajem przedsięwzięcia dwujęzycznego, jakim jest telewizja Arte, dotyczą odbioru warstwy wizualnej przez widzów pochodzących z różnych kręgów językowo-kulturowych. Z jednej strony, bardzo ogólnie można powiedzieć, że obraz ma charakter uniwersalny i zazwyczaj ułatwia rozumienie towarzyszącego mu tekstu, z drugiej jednak może stanowić pewną barierę $\mathrm{w}$ odbiorze i zrozumieniu przekazu audiowizualnego. Jak podkreśla Tomaszkiewicz, te trudności mogą wynikać z dwóch powodów:

-,Z różnych konwencji kulturowych przypisujących znakom niejęzykowym ich znaczenie;

${ }^{1} \mathrm{https}$ //www.dw.com/pl/25-lat-europejskiego-kana\%C5\%82u-arte-kontrapunkt-doobecnej-rzeczywisto\% $\mathrm{C}_{5} \% 9$ Bci/a-39017418 (data dostępu: lipiec, 2018) 
-z różnego bagażu kognitywnego odbiorców oryginału i przekładu. Nie jest to problem związany tylko i wyłącznie z tłumaczeniem audiowizualnym, ale szybkość odbioru przekazu, niemożliwość powrotu czy weryfikacji powoduje, że sens musi być odczytany natychmiastowo.” (2006: 100).

Przykład, który omawiam poniżej stanowi dowód na to, w jaki sposób warstwa wizualna może wpłynąć na decyzje tłumacza. Jest to fragment pochodzący z dziennika Arte Info przetłumaczony z języka francuskiego na niemiecki.

\section{Tabela 1}

\begin{tabular}{|c|c|}
\hline Tekst francuski (tekst wyjściowy) & Tekst niemiecki (tekst docelowy) \\
\hline Materiał filmowy + komentarz & \\
\hline $\begin{array}{l}\text { Le vilain petit canard de ce deuxième } \\
\text { tour, c'est lui : Jean-Claude } \\
\text { Petitdemange. (15.04.2001) }\end{array}$ & $\begin{array}{c}\text { Und das ist der Störenfried : Jean- } \\
\text { Claude Petitdemange, im hellgrauen } \\
\underline{\text { Regenmantel. }}\end{array}$ \\
\hline
\end{tabular}

Jeśli chodzi o stronę językową cytowanego przykładu, to komentarz w języku polskim tłumaczony z języka francuskiego mógłby brzmieć następująco: Oto brzydkie kaczątko tej drugiej tury wyborów: Jean-Claude Petitdemange. Wersja po niemiecku została dodatkowo wzbogacona o sformułowanie: ubrany $w$ jasnoszary płaszcz przeciwdeszczowy. W cytowanym fragmencie newsa mowa była o jednym z kandydatów w wyborach lokalnych w 2001 roku we Francji. Widz mógł zobaczyć na ekranie grupę francuskich polityków, którzy toczyli ożywioną dyskusję. Aby niemieckojęzyczny widz mógł odróżnić od reszty zgromadzonych osób niefrancuskiego polityka, o którym jest mowa w komentarzu, tłumacz wprowadził do tekstu docelowego krótką informację odnoszącą się do rodzaju garderoby Jeana-Claude’a Petitdemange'a. Tłumacz wzią zapewne pod uwagę fakt, że wspomniany francuski polityk jest praktycznie nieznany przez niemieckich widzów, zaś informacja dodana w tłumaczeniu odnosi się do tego, co jest widoczne na ekranie. Tłumacz mógł tego dokonać dzięki obecności warstwy wizualnej i zapewne uczynił to pod jej wpływem.

Z powyższego przykładu wynika również, że tłumacz audiowizualny, podobnie zresztą jak tłumacz tekstów pisanych, „decyduje, jaki obraz oryginału dotrze do odbiorcy przekładu (...), a także - jako pośrednik międzykulturowy - to on może wywierać wpływ na kształtowanie w oczach odbiorcy obrazu kultury, do której należy oryginał" (Skibińska 2008: 11). Silnie zanurzenie tekstu w socjokulturze danego kraju sprawia, że tłumacz może umieścić w tekście docelowym pewną formę eksplicytacji, by ułatwić odbiorcy interpretację komunikatu zgodnie z jego intencją. Zaledwie punktowa i z oczywistych względów zwięzła decyzja tłumacza w cytowanym fragmencie spowodowała, że świat oryginału został nieco bardziej przybliżony odbiorcom przekładu.

Adamowicz-Grzyb we wspominanej wyżej publikacji kilkakrotnie podkreśla znaczenie informacji płynących z ekranu dla tłumacza, który powinien „przyglądać się wszystkim gestom, które czynią bohaterowie i odpowiednio je interpretować. Trzeba pamiętać, że musi być pełna zgodność między gestami na ekranie a wypowiadanymi kwestiami.” (2013: 56). A osiągnięcie takiej zgodności może być 


\section{Paulina Borowczyk: Specyfika pracy thumacza audiowizualnego na przykladzie wybranych komunikatów audiowizualnych}

utrudnione ze względu na odmienność gestów i ich znaczenie w różnych kulturach, jak chociażby przeczący gest głową w Bułgarii, który oznacza twierdzenie.

Z powyższych obserwacji wynika, że tłumacz audiowizualny zawsze przekłada tekst w konfrontacji z materiałem filmowym, gdyż mogą tam się znaleźć elementy, które posłużą mu w redagowaniu tekstu docelowego.

Ponadto, praca tłumacza audiowizualnego jest w dużym stopniu uzależniona od ograniczeń technicznych, „które nakłada na niego odpowiednia metoda zastosowana $\mathrm{w}$ transferze językowym: podpisy, voice-over, dubbing." (Tomaszkiewicz 2006: 102). „Ta pierwsza metoda, przez wymogi i ograniczenia techniczne co do długości, czasu, a także formy graficznej takiego napisu, z góry zakłada skrócenie oraz kondensację tekstu. Tłumacz opracowujący podpisy filmowe ciągle musi decydować, które wartości czy informacje tekstu oryginalnego pominąć, a które z nich zostawić, aby zachować charakter tekstu wyjściowego (Palion-Musioł 2012: 100). Jak przekonuje Adamowicz-Grzyb, dwa z sześciu przykazań tłumacza telewizyjno-filmowego brzmią: Tnij $i$ skracaj oraz Unikaj powtórek. Opracowanie wersji polskiej do zagranicznego filmu nie jest „dosłownym tłumaczeniem wszystkich kwestii wypowiadanych przez bohaterów. Jest to skrótowe wyrażenie ich myśli i intencji (znaczeń). Należy wyjaśniać, dopowiadać, parafrazować i dokonywać syntezy. Skracanie tekstu nie odbywa się w sposób mechaniczny, trzeba go odpowiednio przeredagować (2013: 36). Oczywiście niezmiennie jak w każdym typie przekładu, również i w tym, głównym zadaniem tłumacza jest przekazanie sensu zawartego $\mathrm{w}$ oryginale, jednak w nieco skondensowanej i skróconej formie.

Obliczono, że zazwyczaj usuwa się około 30-40\% tekstu oryginału. „Taka redukcja jest zabiegiem koniecznym, gdyż przeciętny widz czyta wolniej niż dociera do niego zapis dźwiękowy, stąd też, aby mógł on śledzić wszystkie elementy filmowe - dźwięk, obrazy pojawiające się w tym samym czasie na ekranie, muzykę - tekst musi zostać ograniczony do koniecznego minimum, aby współgrać z tymi elementami i tworzyć homogeniczną wizję." (Palion-Musioł 2012: 100). Dlatego też tłumacz musi nieustannie dokonywać wyboru pomiędzy najistotniejszymi informacjami a tymi, które mają charakter drugoplanowy i mogą zostać wyeliminowane z podpisów lub należycie skondensowane.

Przyjęło się, że napisy zajmują dwie linijki liczące od 35 do 38 znaków (łącznie ze spacjami) i umieszczane są w dolnej części ekranu.

„Szacuje się, że widz potrzebuje około 2-3 sekund na przeczytanie jednej pełnej linijki tekstu. A zatem takie ograniczenia techniczne zmuszają tłumacza do kondensacji, za co bywa on często krytykowany przez widza, który uważa, że wykonał zadanie niestarannie, pomijając część informacji przekazanych w oryginale. Oczywiście wspomniana kondensacja musi być uzasadniona i nie może odbywać się przypadkowo. Tłumacz ustawicznie musi podejmować szereg odpowiedzialnych decyzji, dzięki którym tekst w języku docelowym będzie zgodny z intencją i zamysłem autora tekstu źródłowego." (Palion-Musioł, 2012: 101).

$\mathrm{Z}$ jednej strony wspomniane ograniczenia natury przestrzenno-czasowej zmuszają tłumacza do „manipulacji tekstem oryginału w celu otrzymania wersji 
bardziej skondensowanej" (2006: 212), z drugiej jednak w procesie translacji może on wykorzystać fakt, że w przekazach audiowizualnych informacje docierają do widza zarówno w formie tekstów, jak i obrazów i dźwięków. W jaki sposób? Dzięki temu, że tekst pojawia się $\mathrm{w}$ określonym kontekście fabularnym oraz dzięki informacjom płynącym $\mathrm{z}$ ekranu tłumacz może skrócić niektóre dialogi. Przyjrzyjmy się zatem dwóm następującym przykładom zaczerpniętym z publikacji Arkadiusza Belczyka Ttumaczenie filmowe (2007: 29):

\section{Tabela 2}

\begin{tabular}{|c|c|}
\hline Tekst angielski (tekst wyjściowy) & Tekst polski (tekst docelowy) \\
\hline Am I safe in this crate ? & Jestem tu bezpieczna? \\
\hline
\end{tabular}

W pierwszym przykładzie tłumacz posłużył się w tłumaczeniu na język polski „wyrażeniem deiktycznym zamiast precyzyjnego nazwania jakiegoś detalu, jak to czyni oryginalny tekst" (Belczyk 2007: 28). Na ekranie widoczna jest kobieta, która chowa się w skrzyni i pyta: Am I safe in this crate ? Ponieważ na ekranie wyraźnie widać jej kryjówkę, tłumacz nie musi dodatkowo informować o tym widzów, wystarczy więc napisać: Jestem tu bezpieczna?” (2007: 29).

W drugim przypadku widzimy klienta, który wchodzi do salonu samochodowego i wskazując ręką na samochód, zadaje pytanie: Excuse-me. Can I test-drive this car? „Końcówkę tego pytania-prośby można w tłumaczeniu pominąć, gdyż została wyrażona odpowiednim gestem; polski napis wystarczy zatem ograniczyć do Przepraszam, mógłbym się przejechać? (Belczyk 2007: 28).

\section{Tabela 3}

\begin{tabular}{|c|c|}
\hline Tekst angielski (tekst wyjściowy) & Tekst polski (tekst docelowy) \\
\hline Excuse-me. Can I test-drive this car? & $\begin{array}{c}\text { Przepraszam, mógłbym się } \\
\text { przejechać? }\end{array}$ \\
\hline
\end{tabular}

Możliwe są również uproszczenia treści napisów odwołujące się do szerszego kontekstu filmu czy jakichś wcześniejszych wypowiedzi padających z ekranu, a nie tylko do jednej konkretnej sceny (jak to miało miejsce w poprzednich przykładach). Prosty przykład: jeden z bohaterów pyta drugiego: Tu voudrais qu’il te pardonne alors que tu lui as volé la drogue ? (pol. Chciatbyś, żeby ci przebaczyt, mimo że ukradteś mu narkotyki ?) Kilka minut wcześniej widz widział scenę kradzieży narkotyków, dlatego tłumacz nie musi przypominać, o jakiej kradzieży dokładnie jest mowa - nawet jeśli to ważna informacja. Dlatego tłumacz zredukował polski przekład do dużo krótszego: Myślisz, że daruje ci kradzież?

\section{Tabela 4}

\begin{tabular}{|c|c}
\hline Tekst francuski (tekst wyjściowy) & Tekst polski (tekst docelowy) \\
\hline $\begin{array}{c}\text { Tu voudrais qu'il te pardonne alors que } \\
\text { tu lui as volé la drogue? }\end{array}$ & Myślisz, że daruje ci kradzież? \\
Film : L'empire des loups (Francja, & \\
2005)
\end{tabular}




\section{Paulina Borowczyk: Specyfika pracy thumacza audiowizualnego na przyktadzie wybranych komunikatów audiowizualnych}

Dokonywanie pominięć oraz stosowanie zabiegów kondensacyjnych, które wynikają z wymogów technicznych w filmie, sprawiają, że tekst docelowy ulega znacznym modyfikacjom. Uzyskane tłumaczenie powinien cechować prosty styl, a zdania winny być krótkie i logiczne, bez skomplikowanej budowy. Oczywiście tłumacz powinien jednak pamiętać, że tłumaczenie w formie podpisów „nie może być przekazem telegraficznym, gdyż widz czytając je, musi mieć wrażenie, że chodzi o autentyczne dialogi, a nie ich streszczenie" (Tomaszkiewicz 2006:135).

Kolejnym ciekawym przykładem jest scena pochodząca $\mathrm{z}$ animowanego filmu dla dzieci pt. „Madagaskar” z 2005 roku:

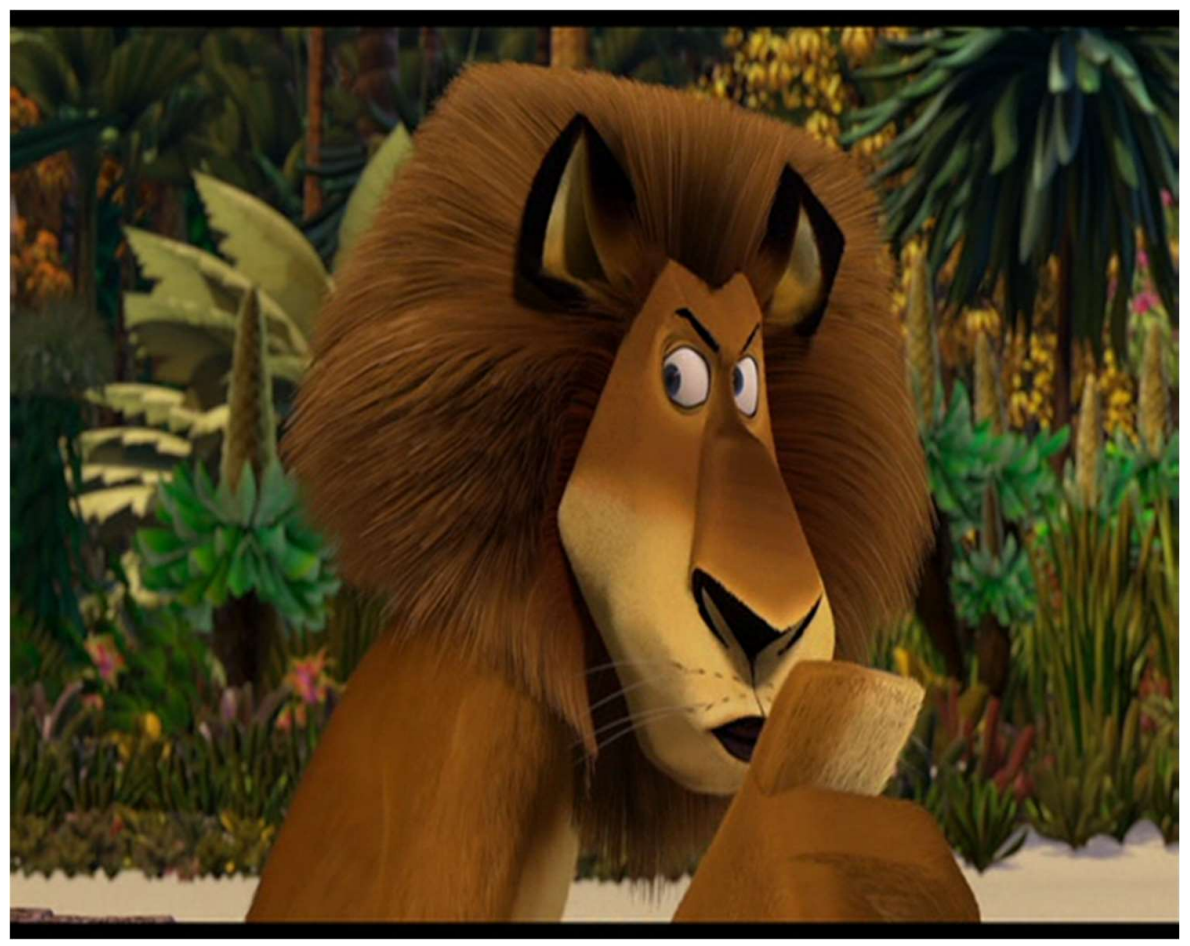

Tabela 5

\begin{tabular}{|c|c|c|}
\hline $\begin{array}{c}\text { Tekst angielski (tekst } \\
\text { wyjściowy) }\end{array}$ & Tekst polski (dubbing) & Tekst polski (napisy) \\
\hline Alex: Shush! & Cicho! & - \\
\hline
\end{tabular}

Na przedstawionej powyżej klatce z filmu (gest wykonywany przez lwa Aleksa mający na celu rozkazanie reszcie bohaterów zachowanie ciszy) oraz towarzyszącej jej wypowiedzi (angielski wykrzyknik: Shush!, pol. Cicho!) można zaobserwować, że ta sama informacja jest przekazywana dwoma kanałami: wizualnym i werbalnym. Dzięki obecności gestu na ekranie i jego uniwersalnemu znaczeniu tłumacz przygotowujący polskie napisy do filmu pominął wypowiedź bohatera. Mimo braku napisu scena pozostaje czytelna i całkowicie zrozumiała.

Jak ilustrują powyższe przykłady, nie należy zapominać, że obraz i dźwięk tworzą nierozerwalną część z dialogami oraz narracją i nieustannie im towarzyszą. To właśnie w odniesieniu do warstw pozawerbalnych tłumacz tworzy jasny, 
przejrzysty i zrozumiały przekaz, w myśl zasady „im większa grupa docelowa, tym prostszy język.” (Adamowicz-Grzyb 2013: 51).

Głównym celem niniejszego artykułu było uświadomienie złożoności pracy tłumacza audiowizualnego, która wynika z mnogości elementów i czynników, jakie należy wziąć pod uwagę podczas przekładu komunikatów audiowizualnych. Tłumaczeniu podlegają przede wszystkim wypowiedzi bohaterów (umieszczone i dostarczone tłumaczowi $\mathrm{w}$ formie list dialogowych), jednak ich uwikłanie $\mathrm{w}$ przemyślaną przez autorów filmu przestrzeń audiowizualną, jak i intertekstualną sprawia, że mamy do czynienia z materią niezwykle złożoną i wielowymiarową. Jak zauważa Adamowicz Grzyb, „tłumacz telewizyjno-filmowy w codziennej pracy musi - niemal jak multiinstrumentalista - wykazać się wieloma, bardzo różnorodnymi umiejętnościami” (2013: 13). „Powinien wykazać się biegłością (...) w sztuce przekładu, znajomością telewizyjno-filmowej „kuchni”, podstaw emisji głosu, poprawności językowej (2013: 224). Również nowoczesne nośniki, na których rejestruje się materiały filmowe wymagają od tłumacza znajomości współczesnych technologii. Wnikliwa analiza zarówno listy dialogowej i warstwy wizualnej filmu/reportażu do tłumaczenia to proces wieloetapowy i wielopłaszczyznowy. Zatem pogląd, że praca tłumacza audiowizualnego należy do łatwych i przyjemnych jest krzywdzący i nieprawdziwy. 


\section{Paulina Borowczyk: Specyfika pracy thumacza audiowizualnego na}

przykladzie wybranych komunikatów audiowizualnych

\section{Bibliografia}

Adamowicz-Grzyb, G. 2013. Thumaczenia filmowe $w$ praktyce. Warszawa: FORTIMA Tłumaczenia-Edukacja-Media.

Belczyk, A. 2007. Ttumaczenie filmów. Wilkowice: Wydawnictwo Dla Szkoły.

Garcarz, M. 2007. Przekład slangu w filmie. Telewizyjne przekłady filmów amerykańskich na język polski. Język a komunikacja, vol. 15, Kraków : Tertium.

Nowak, A. 2006. Les éléments des dialogues filmiques qui subissent la suppression pendant la traduction en forme des sous-titres sur l'exemple du film français "L'empire des loups ». (praca licencjacka napisana pod kierunkiem dr Pauliny Borowczyk w Zakładzie Traduktologii i Badań nas Kanadą Frankofońską), Poznań.

Palion-Musioł, A. 2012. Przekład audiowizualny jako wyzwanie dla współczesnego tłumacza. Narzędzia oraz metody wykorzystywane w procesie translatorycznym. Rocznik przekładoznawczy, Studia nad teoria, praktyka $i$ dydaktyka przekładu, vol. 7, pp. 95-107.

Plewa, E. 2015. Układy translacji audiowizualnych. Studi@ Naukowe, vol. 28, Warszawa: Wydawnictwo Naukowe Instytutu Komunikacji Specjalistycznej i Interkulturowej.

Sikora, I. 2013. Dubbing filmów animowanych. Strategie translatorskie $w$ polskim dubbingu anglojęzycznych filmów animowanych. Nysa: Oficyna Wydawnicza PWSZ.

Skibińska, E. 2008. Kuchnia ttumacza. Studia o polsko-francuskich relacjach przekładowych. Kraków: Universitas.

Szarkowska, A. 2009. Przekład audiowizualny w Polsce - perspektywy i wyzwania. Przektadaniec, vol. 20, pp. 8-25.

Tomaszkiewicz, T. 2006. Przekład audiowizualny. Warszawa: Wydawnictwo Naukowe PWN.

@: $\quad$ https://www.dw.com/pl/25-lat-europejskiego-kana\%C5\%82u-artekontrapunkt-do-obecnej-rzeczywisto\%C5\%9Bci/a-39017418 (data dostępu: lipiec, 2018). 